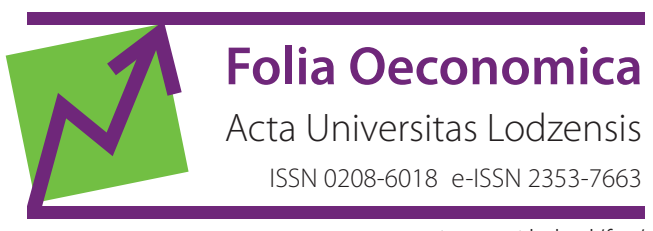

www.czasopisma.uni.lodz.pl/foe/

2(328) 2017

DOI: http://dx.doi.org/10.18778/0208-6018.328.05

\title{
Edyta Łaszkiewicz
}

University of Lodz, Faculty of Economics and Sociology, Department of Spatial Econometrics, elaszkiewicz@uni.lodz.pl

\section{Anna Bojanowska}

University of Lodz, Faculty of Economics and Sociology, Department of Labour and Social Policy, anna.bojanowska89@gmail.com

\section{The Future of Polish Labour Market and the Issue of Work Motivation in Older People}

\begin{abstract}
According to the demographic forecasts, the population of people in their productive working age decreases, while the share of people aged 65 and over increases. The negative demographic tendencies will affect the conditions of labour market. If the workers' activity rate doesn't rise, the total number of workers will decrease dramatically. The demographical pressures on the labour market should result in a prolonging of people's professional activity. The increase of the labour market activity seems to be one of the most important goals for Poland, for the coming years. One of the factors, which might help in maintaining the high rate of labour market activity (especially among those who are in the pre-retirement age) is the adaptation of working conditions to the needs of people of various ages. The possibility of working remotely, the flexibility of weekly hours of work or the financial benefits might motivate younger and older workers in different ways. Hence, the use of mechanisms which support the economic activity of older people requires an identification of solutions which will benefit this group of workers the most. The aim of this research is the identification of age-related differences in factors which motivate workers to continuing working activity. We used the database of individuals from Polish Social Diagnosis (for 2015) and applied the logit regression models to verify if there are age differences in the way people prefer to be motivated to work. We found that what motivates elderly workers doesn't always motivate the others in the same way. Pre-retirement age workers prefer, more than others, to be independent and to have a job which is related to their experience. The financial motivators as well as the stability of employment, although very important for all workers, seem to be less important for the elderly workers because they have achieved pension rights.
\end{abstract}

Keywords: job satisfaction, labour market, management of diversity, age-related differences

JEL: J14, J28, C25 


\section{Introduction}

The condition of labour market is strongly connected to the demographical trajectories, which currently show a decline in birth rates and an increase in the numbers of elderly people, who represent the post World War II baby boom generation. Hence, to guarantee the stabilisation on the labour market in the future, it is crucial to rise the employment rate among the elderly, which, in Poland, is still one of the lowest out of all of the EU states. (44.3\% for people aged 55-64 in Poland and $53.3 \%$ for EU28 in 2015). Among various strategies, which are concentrating on improving activity of the elderly on the labour market, the strategy of diversity management seems to be important.

Due to the conception of diversity management, differences between groups of employees are taken into account, in e.g. training or motivating, to enables people to work to their full potential. Although the common source of the differences which diversify management strategy is the cultural background of employees, it is hard to deny the existence and the effect of age-related differences on the way an organization might manage their employees. Resulting from the above, the aim of our study is to verify if there are any differences in the way that elderly employees should be motivated to work. We hypothesize that there is no one way to motivate the older and younger employees in order to assure their needs' satisfaction.

This paper is organized as follows: section 2 provides main demographical tendencies in Poland. Section 3 discusses the consequences of aging population for the labour market, while section 4 presents briefly the concept of diversity management. In Section 5, the data are described and a statistical summary is provided, while section 6 presents specification of logit models. The empirical results with interpretation and discussion are provided in section 7. In section 8 we discuss the robustness of our results. Finally, section 9 draws conclusions.

\section{Demographical trends and projections}

The demographical situation in Poland is driven mainly by two forces - the systematic reduction of births and the increasing number of older people. On one hand, from 2002 to 2015 demographic dynamics rate ${ }^{1}$ in Poland declined from 0.98 to 0.94 (GUS, 2015). Since 1990, such a low ratio of birth cannot guarantee a simple replacement of generations. In 2015 only 129 births were noted per every 100 women aged 15-49, which proves that a diminishing of the labour force will be observed in Poland in the future.

On the other hand, rapid progress in medicine (e.g. better access to medical services and the improvement of quality of those services), as well as better condi-

\footnotetext{
${ }^{1}$ Number of live births divided by the number of deaths.
} 
tions of life and the growing awareness of the importance of healthy living result in systematic lengthening of life. In Poland, the dynamic growth of life expectancy at birth began in 1992 and in 2015 reached 73.6 years for men and around 81.6 for women (GUS, 2016). Moreover, the share of the healthy life years in the total life expectancy was $81.2 \%$ for males and $76.8 \%$ for females in 2014 (Eurostat, 2016). This means longer lives with longer periods lived in health, which in turn means a population growth due to the decline in mortality rates. If we assume that the decline in mortality rates in Poland acts in similarly to that of Western Europe, then in 2050 an average life expectancy will be approximately $81.8-84.1$ for men and 87.6-89 for women (GUS, 2014).

An increase of the average life expectancy and the decline of the fertility rates will cause a new problem in Poland, present in other European countries for some time, namely: an aging population. This phenomenon is not unusual in European societies. Its severity depends on the stage of development of the society. In Europe, it appeared in the nineteenth century in countries such as the United Kingdom, Sweden, Denmark and France (World Bank, 2012). Its appearance was closely linked to the socio-economic changes brought by the industrialization and urbanization. All of this resulted in a change in migration and population associated with the demographic transition. Over the past 100 years, this process has spread throughout Europe and currently it is also present in Poland.

The aging population means increasing proportion of older people with a decline in the percentage of children. According to the UN, a population is considered old when the share of population aged 65 and over is more than $7 \%$ of the total population. When the proportion exceeds $10 \%$ of the total population, this means the population is entering the phase of advanced age (WHO, 2011). Forecasts for Poland clearly confirm that by 2050 we will observe significant decrease of population in pre-working age (by $28 \%$ comparing with 2015 ) and working age (21\%) as well as an increase in the number of people in post-working age (32\%).

\section{The consequences for labour market}

Ageing population will have a huge impact on the future of social security and labour market. The most significant changes are related to the age of the population in the post-production age and the evolution of its internal structure. In the coming years we will witness an increase in both mobile and immobile citizens, which will have an impact on the entire Polish population (Duszczyk et al., 2016). Until 2013, the retirement age in Poland was 59 years for women and 64 for men. As the result of changes in the law on pensions from the Social Insurance Fund and certain other acts, the new retirement age, introduced in 2013, is now 67 years old, both for men and women (Journal of Laws of 2012, pos. 637). 
The increase of the retirement age demonstrated the necessity for searching for the way to stabilize the future of the labour market in Poland. It requires the pay-as-you-go (PAYG) social security in which the ones responsible for pensions of the current generation in production are those who are currently in pre-production age (Szczepański, 2015). According to the forecasts, the gap will be too big to be able to survive the current retirement system. Another problem is a decreasing number of people in production age who will be available on the labour market. Therefore, it would seem that the priority for our country would be to focus on the increase of birth rates and the extension of the retirement age or even on the encouragement of people to stay in the labour market for as long as possible (Maier, 2015).

\section{Management of diversity}

Less than a decade ago, the management of diversity was seen as a tool for promoting anti-discriminatory attitude. With the increasing globalization, competition and the desire for individualization of products and services, it has become a key to the success of a company (UNESCO, 2009). Managing diversity has become a thought-out strategy for companies, leading to the most effective goal achievement through the use of various experiences and needs, both within the organization and within its immediate surrounding (Lisowska, Sznajder, 2013) In other words, the current diversity management is a process of management and communication strategies which actively and consciously perceives future benefits in directing an organization based on values and acceptance of differences. Moreover, it treats them as a trigger for company development, in a deliberately thought out, implemented and properly conducted process (Amershi et al., 2007).

For the proper administration of diversity management process, the differences between employees need to be identified. It is widely understood, that diversity is really nothing more than a value, which properly directed can improve the quality of the company and have a positive impact on it (Harvey, Allard, 2015: 414). With this approach we do not focus exclusively on creating favourable conditions for the unit or on equalization of opportunities for a group of employees. We assume that the whole organization consists of individuals with unique talents but also weaknesses that need to be optimally reoriented. Through such approach the burden of diversity shifts from the individual to the company, recognizing that diversity in itself becomes a significant value (Bleijenbergh et al., 2016).

To explore the concept of diversity management - and even more so - to make it beneficial for an enterprise, we need to understand what diversity is. For systematization, the differentiating factors can be divided into primary and secondary. The primary factors (like: race, age, gender, sexual orientation and physical or in- 
tellectual disability) are not dependent on the individual. As the secondary factors we consider, among other things: the level of education, marital status, religion, place of residence, language, value system or social class. What is important, differentiating factors are not only the features that an employee brings to the organization from the outside, but also the ones he or she is shaped with from within the organisation, such as the position in the hierarchy, seniority, form of employment or even a union membership (Fazlagić, 2014). In the broadest sense of the subject we can consider such differentiating elements to be the individual character of an employee (Walczak, 2011).

For the purposes of this article we will focus on age as a differentiating element. In accordance with the principles of diversity management it is necessary for the managers to look at their own team. Once we see what differences exist between its members, we can take further steps to educate the team and enable its good communication and cooperation. In this article, however, we touch upon another matter. Managing diversity also consists of the use of various incentive schemes aimed at different members of the team. This is due to the fact that the team usually consists of a wide spectrum of individuals with unique skills and needs. Therefore, it is necessary to recognize that there is a difference between people of production age and those in post-production age.

\section{Database and statistical summary}

To analyse factors which play the crucial role in motivating older workers to continuing labour market activity we used micro data from Polish Social Diagnosis for 2015. The responses to individual questionnaires were given by people aged 16 and over. After weighting, the sample of $N=24324$ individuals is country representative (Czapiński, Panek, 2015: 28).

From the whole sample, 11813 are those who had a job at the time of the interview. This subsample may be further divided into two groups: pensioners and others. By pensioners we mean men aged 65 and over and women aged 60 and over. This age limit was used to include both those who are pensioners and those older who have not reached the retirement age yet. As a result, we obtained a subsample of 426 elderly people who are retired or are before (but close to) retirement age and are still working.

Crucial for our study were answers to the question about the factors which are the most important in professional work. Each respondent could choose maximum 3 factors from 12, according to personal opinion. The comparison of answers for elderly workers and others is shown in Figure 1.

As we expected, the factors which motivate elderly and other workers to continuing labour market activity are not the same. The only noted similarities are 
of small importance: long leave and having a profession which is respected by others. Moreover, both for elderly and other workers lack of tension and stress plays a crucial role in a work place. What might be a surprise, is that elderly workers do not concentrate more than others on this factor as a worker motivator.

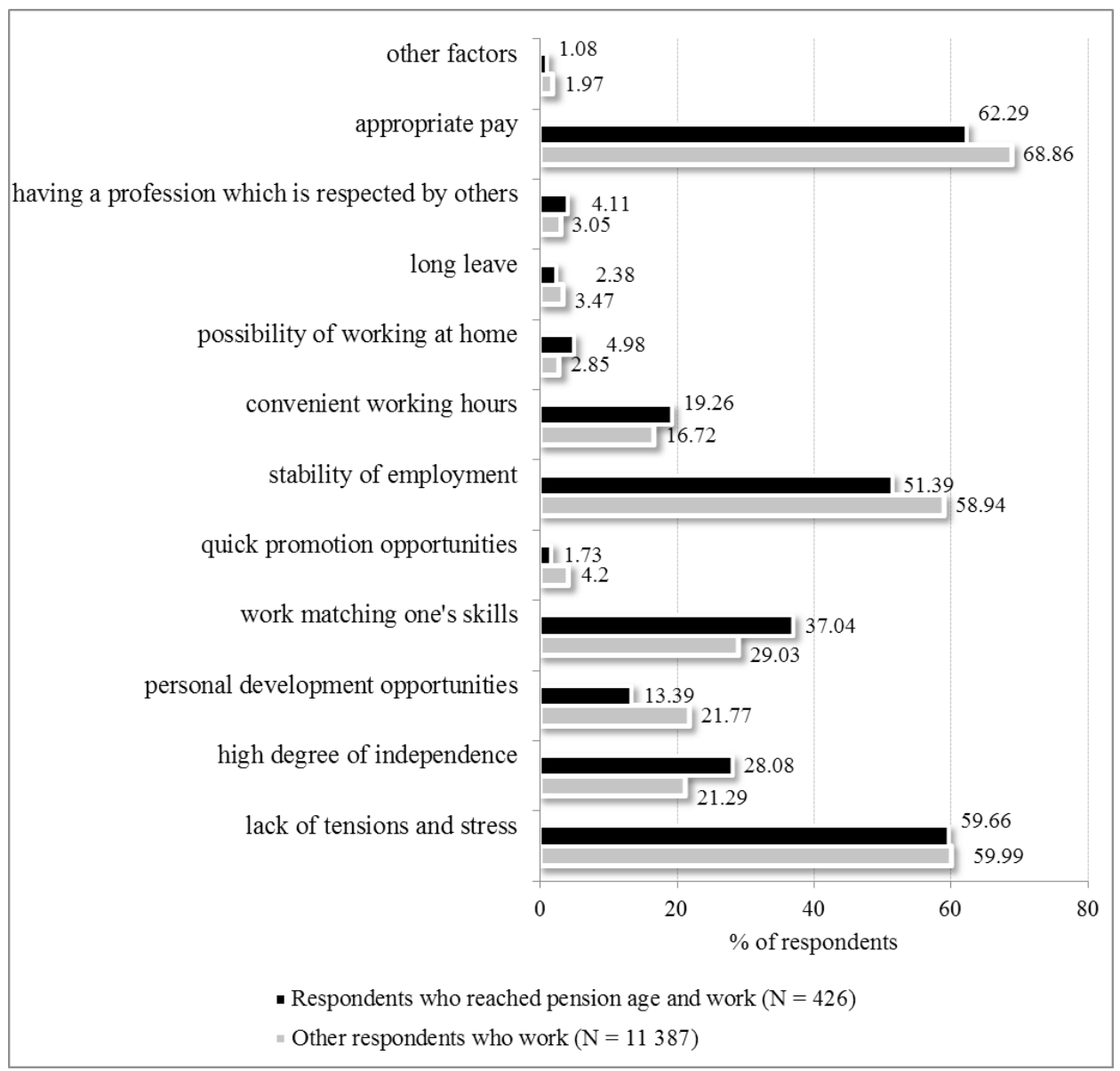

Figure 1. Factors motivating elderly and others to work

Source: own calculation based on data from Social Diagnosis

The comparison of elderly and other workers shows there are five crucial factors, which differentiate both groups in the way they need to be motivated. For elderly workers high degree of independence and work matching one's skills are more important than for others. It seems they are less flexible at work, which further proves that personal development opportunities are less important for them. Such workers might prefer to be mentors and to share their experience with other workers. Surprisingly, while pre-retirement age workers can be perceived as want- 
ing stability above all, according to our results, stability of employment was not as frequent a desire within this group as it was for the other respondents. As our results might have been affected by the existence of other factors, which differentiate the responses in both groups, further analysis is needed.

\section{Binary logit regression model}

According to the above, we decided to analyse in more detail the five working motivators for which differences between elderly workers and others were the greatest. We endeavoured to examine if the occurring differences were the result of between-group variations of personal attributes, like: sex, educational level, disability, etc. For this purpose, we estimated binary logit models, separately for each motivator, using the same set of explanatory variables every time. The general formula of the model is as follows (Gruszczyński, 2012: 80):

$$
p_{i}=\frac{\exp \left(x_{i}^{\prime} \beta\right)}{1+\exp \left(x_{i}^{\prime} \beta\right)}=\frac{1}{1+\exp \left(-x_{i}^{\prime} \beta\right)},
$$

where: $p_{i}$ - probability of choosing the factor as a working motivator by respondent $i$. The specification of explanatory variables with descriptive statistics are presented in Table 1.

Table 1. Definitions and summary statistics for explanatory variables

\begin{tabular}{|l|l|c|c|}
\hline \multicolumn{1}{|c|}{ Name } & \multicolumn{1}{|c|}{ Description } & $\begin{array}{c}\text { \% } \\
\text { or mean }\end{array}$ & N \\
\hline pension age & $\begin{array}{l}\text { dummy variable which takes the value 1 if respondent } \\
\text { achieved (pre)retirement age and 0 otherwise }\end{array}$ & 3.61 & 11813 \\
\hline sex & $\begin{array}{l}\text { dummy variable which takes the value 1 if woman and 0 } \\
\text { otherwise }\end{array}$ & 46.11 & 11812 \\
\hline disability & $\begin{array}{l}\text { dummy variable which takes the value 1 if respondent } \\
\text { had a disability certificate and 0 if not }\end{array}$ & 3.50 & 11801 \\
\hline health & $\begin{array}{l}\text { subjective health satisfaction; 1-very satisfied, 6- very } \\
\text { unsatisfied }\end{array}$ & 2.60 & 11792 \\
\hline self employment & $\begin{array}{l}\text { dummy variable which takes the value 1 if respondent } \\
\text { is self-employed and 0 otherwise }\end{array}$ & 8.34 & 11813 \\
\hline unemployment & $\begin{array}{l}\text { number of times respondent was registered as unem- } \\
\text { ployed during the whole life }\end{array}$ & 10.02 & 11382 \\
\hline manager & $\begin{array}{l}\text { dummy variable which takes the value 1 if respondent } \\
\text { work in a managerial capacity and 0 if not }\end{array}$ & 12.08 & 11766 \\
\hline household size & size of household measured by number of persons & 3.74 & 11791 \\
\hline
\end{tabular}




\begin{tabular}{|l|l|r|c|}
\hline \multicolumn{1}{|c|}{ Name } & \multicolumn{1}{|c|}{ Description } & \multicolumn{1}{c|}{$\begin{array}{c}\text { \% } \\
\text { or mean }\end{array}$} & $N$ \\
\hline \multicolumn{3}{|c|}{ educational level (lower as reference category): } \\
\hline basic vocational & $\begin{array}{l}\text { dummy variable which takes the value 1 if individual has } \\
\text { basic vocational education level and 0 otherwise }\end{array}$ & 27.85 & 11791 \\
\hline $\begin{array}{l}\text { secondary edu- } \\
\text { cation }\end{array}$ & $\begin{array}{l}\text { dummy variable which takes the value 1 if individual has } \\
\text { secondary education level and 0 otherwise }\end{array}$ & 30.86 & 11791 \\
\hline higher education & $\begin{array}{l}\text { dummy variable which takes the value 1 if individual has } \\
\text { higher education level and 0 otherwise }\end{array}$ & 36.18 & 11791 \\
\hline \multicolumn{1}{|c|}{ important condition of a successful, happy life: } \\
\hline money & $\begin{array}{l}\text { dummy variable which takes the value 1 if the factor } \\
\text { is important for happy life in the opinion of respondent } \\
\text { and 0 if not }\end{array}$ & 27.63 & 11652 \\
\hline work & \multicolumn{2}{|c|}{37.78} & 11692 \\
\hline freedom & & 5.60 & 11621 \\
\hline
\end{tabular}

Source: own calculation based on Social Diagnosis

Binary logit regression models were estimated using maximum likelihood method (Gruszczyński, 2012: 81-82). We used robust standard error estimators to avoid the consequences of potential heteroscedasticity.

\section{Empirical results and discussion}

In Tables $2-5$ we presented the estimated coefficients from logit models with odds ratios and average marginal effects (AME). According to our results, after controlling individual and work-related factors, the difference between elderly workers and others in the probability of preferring particular working motivator is still significant. The probability of choosing work matching one's skills or allowing a high degree of independence, as the factor motivating to work, is significantly higher (by around $11 \%$ ) in the group of elderly workers. In contrast, the probability of choosing personal development opportunities, stability of employment or appropriate pay as the working motivator is significantly lower (by around 6-7\%) for elderly workers.

Preferences reported by employees as far as the motivation strategy is concerned, prove the lower willingness of the elderly workers to learn new things. They seem to be less flexible than others and put less emphasis on personal development. This is consistent with the employers' opinion. As pointed out by Kołodziejczyk-Olczak (2014: 198-199) the workers aged 45+ are seen as negatively-oriented towards training and cooperation in traditional organizations, while knowledge-based organizations suffer more because of the limited possibility of re-assigning older workers to different positions.

The place of elderly workers in the structure of organization might be unclear. However, while we take into account that they prefer to be independent and use their current knowledge, it is easy to conclude that they should be involved in sharing their experience, transferring knowledge and training other workers. Such actions 
might convince them about their independence and let them know they are still useful for the organization as professionals. Our results suggest that the customization of workplace towards the needs of elderly workers does not have to be expensive. Although the appropriate salary is one of the most important working motivators for all workers, older workers are less insistent on financial gratification than others.

Table 2. Estimation results for motivating by work matching one's skills

\begin{tabular}{|l|c|c|c|}
\hline \multicolumn{1}{|c|}{ Variable } & $\boldsymbol{\beta}$ & Odds ratio & AME \\
\hline const. & $-1.106^{* * *}$ & 0.331 & \\
\hline pension age & $0.532^{* * *}$ & 1.703 & 0.117 \\
\hline sex & $-0.128^{* *}$ & 0.880 & -0.026 \\
\hline disability & 0.148 & 1.159 & 0.030 \\
\hline health & -0.012 & 0.988 & -0.002 \\
\hline self employment & $0.199^{*}$ & 1.220 & 0.041 \\
\hline unemployment & -0.083 & 0.920 & -0.017 \\
\hline manager & -0.041 & 0.960 & -0.008 \\
\hline household size & 0.002 & 1.002 & 0.0004 \\
\hline basic vocational & 0.106 & 1.112 & 0.021 \\
\hline secondary education & 0.022 & 1.022 & 0.004 \\
\hline higher education & $0.250^{*}$ & 1.283 & 0.050 \\
\hline money & 0.002 & 1.002 & 0.004 \\
\hline work & $0.190^{* *}$ & 1.210 & 0.038 \\
\hline freedom & 0.074 & 1.077 & 0.015 \\
\hline Log likelihood & \multicolumn{3}{|l}{} \\
\hline McFadden's $R^{2}$ & -6521 & \\
\hline
\end{tabular}

Significant at the 0.01 level $* * *, 0.05 * *, 0.1 *$

Although our main goal was to confirm the age-related differences as far as the preferred working motivators are concerned, the results from the logit models gave us some synthetic information about additional factors which can affect the strategy of motivation. The health status, which is usually mentioned as a determinant of productivity (Tompa, 2002), also influences the motivational preferences. We found that the healthier the worker, the higher the probability that he or she prefers to be independent at work and to invest in personal development. The appropriate pay is however less important for healthy workers than for those in poor health.

Moreover, previous experience in the labour market also affects the motivational strategy. Workers who were unemployed in the past, are less interested in high degree of independence and prefer more often than others the stability of employment. Within some of the working motivators, the choice is related to the workers' personality. Those for whom money is an important element of a success- 
ful life, prefer to be motivated by an appropriate pay. Freedom as a crucial value in happy life corresponds to a stronger need for personal development, while those who concentrate on work, prefer more frequently to work in stable environment and a job that matches their skills. Finally, the probability of choosing a particular working motivator depends on the worker's position within the company. Managerial staff tend to be motivated less by financial gratification and more by possibility of self-development as well as a high level of independence.

Table 3. Estimation results for motivating by personal development opportunities

\begin{tabular}{|l|c|c|c|}
\hline \multicolumn{1}{|c|}{ Variable } & $\boldsymbol{\beta}$ & Odds ratio & AME \\
\hline const. & $-1.843^{* * *}$ & 0.158 & \\
\hline pension age & $-0.853^{* * *}$ & 0.426 & -0.115 \\
\hline sex & 0.028 & 1.028 & 0.005 \\
\hline disability & 0.037 & 1.038 & 0.006 \\
\hline health & $-0.058^{*}$ & 0.944 & -0.010 \\
\hline self employment & -0.165 & 0.848 & -0.026 \\
\hline unemployment & 0.020 & 1.020 & 0.003 \\
\hline manager & $0.381^{* * *}$ & 1.464 & 0.067 \\
\hline household size & $-0.040^{* * *}$ & 0.961 & -0.007 \\
\hline basic vocational & 0.230 & 1.258 & 0.023 \\
\hline secondary education & $0.740^{* * *}$ & 2.096 & 0.091 \\
\hline higher education & $1.596^{* * *}$ & 4.932 & 0.257 \\
\hline money & $-0.140^{*}$ & 0.869 & -0.023 \\
\hline work & -0.095 & 0.909 & -0.016 \\
\hline freedom & $0.379^{* *}$ & 1.460 & 0.067 \\
\hline Log likelihood & \multicolumn{3}{|l}{} \\
\hline McFadden's $R^{2}$ & -5602 & 0.073 \\
\hline
\end{tabular}

Significant at the 0.01 level ${ }^{* * *}, 0.05^{* *}, 0.1$ *

\section{Source: own calculation based on Social Diagnosis}

Table 4. Estimation results for motivating by stability of employment guarantee

\begin{tabular}{|l|c|c|c|}
\hline \multicolumn{1}{|c|}{ Variable } & $\boldsymbol{\beta}$ & Odds ratio & AME \\
\hline const. & $0.564^{* * *}$ & 1.759 & \\
\hline pension age & $-0.286^{* *}$ & 0.751 & -0.070 \\
\hline sex & 0.032 & 1.033 & 0.008 \\
\hline disability & 0.084 & 1.087 & 0.020 \\
\hline health & -0.022 & 0.978 & -0.005 \\
\hline self employment & $-0.629^{* * *}$ & 0.533 & -0.155 \\
\hline unemployment & $0.132^{*}$ & 1.141 & 0.032 \\
\hline manager & -0.109 & 0.897 & -0.026 \\
\hline household size & -0.015 & 0.985 & -0.004 \\
\hline basic vocational & -0.099 & 0.906 & -0.024 \\
\hline secondary education & -0.113 & 0.893 & -0.027 \\
\hline
\end{tabular}




\begin{tabular}{|l|c|c|c|}
\hline \multicolumn{1}{|c|}{ Variable } & $\boldsymbol{\beta}$ & Odds ratio & AME \\
\hline higher education & -0.048 & 0.953 & -0.011 \\
\hline money & $-0.141^{* *}$ & 0.869 & -0.034 \\
\hline work & $0.158^{* * *}$ & 1.171 & 0.038 \\
\hline freedom & -0.108 & 0.897 & -0.026 \\
\hline Log likelihood & \multicolumn{3}{|c|}{-7455} \\
\hline McFadden's $R^{2}$ & \multicolumn{3}{|c|}{0.010} \\
\hline
\end{tabular}

Significant at the 0.01 level ${ }^{* *}, 0.05^{* *}, 0.1 *$.

Source: own calculation based on Social Diagnosis

Table 5. Estimation results for motivating by high degree of independence

\begin{tabular}{|l|c|c|c|}
\hline \multicolumn{1}{|c|}{ Variable } & $\boldsymbol{\beta}$ & Odds ratio & AME \\
\hline const. & $-1.218^{* * *}$ & 0.296 & \\
\hline pension age & $0.630^{* * *}$ & 1.877 & 0.116 \\
\hline sex & $-0.265^{* * *}$ & 0.767 & -0.042 \\
\hline disability & $-0.403^{* * *}$ & 0.668 & -0.058 \\
\hline health & $-0.106^{* * *}$ & 0.899 & -0.017 \\
\hline self employment & $1.001^{* * *}$ & 2.721 & 0.197 \\
\hline unemployment & $-0.314^{* * *}$ & 0.731 & -0.050 \\
\hline manager & $0.445^{* * *}$ & 1.560 & 0.078 \\
\hline household size & 0.0005 & 1.000 & 0.0001 \\
\hline basic vocational & -0.090 & 0.914 & -0.013 \\
\hline secondary education & 0.087 & 1.091 & 0.014 \\
\hline higher education & 0.201 & 1.222 & 0.032 \\
\hline money & 0.024 & 1.025 & 0.004 \\
\hline work & 0.098 & 1.103 & 0.016 \\
\hline freedom & 0.157 & 1.170 & 0.026 \\
\hline Log likelihood & \multicolumn{3}{|l}{} \\
\hline McFadden's $R^{2}$ & -5501 & \\
\hline
\end{tabular}

Significant at the 0.01 level ${ }^{* * *}, 0.05^{* *}, 0.1 *$.

Source: own calculation based on Social Diagnosis

Table 6. Estimation results for motivating by appropriate pay

\begin{tabular}{|l|c|c|c|}
\hline \multicolumn{1}{|c|}{ Variable } & $\boldsymbol{\beta}$ & Odds ratio & AME \\
\hline const. & $0.508^{* * *}$ & 1.662 & \\
\hline pension age & $-0.288^{* *}$ & 0.750 & -0.065 \\
\hline sex & 0.016 & 1.016 & 0.003 \\
\hline disability & -0.129 & 0.879 & -0.028 \\
\hline health & $0.078^{* * *}$ & 1.081 & 0.017 \\
\hline self employment & 0.020 & 1.020 & 0.004 \\
\hline unemployment & $0.247^{* * *}$ & 1.280 & 0.053 \\
\hline manager & $-0.313^{* * *}$ & 0.731 & -0.070 \\
\hline
\end{tabular}




\begin{tabular}{|l|c|c|c|}
\hline \multicolumn{1}{|c|}{ Variable } & $\boldsymbol{\beta}$ & Odds ratio & AME \\
\hline household size & $0.029^{*}$ & 1.030 & 0.006 \\
\hline basic vocational & -0.008 & 0.992 & -0.002 \\
\hline secondary education & -0.111 & 0.895 & -0.024 \\
\hline higher education & -0.200 & 0.819 & -0.043 \\
\hline money & $0.204^{* * *}$ & 1.226 & 0.043 \\
\hline work & 0.013 & 1.013 & 0.003 \\
\hline freedom & 0.014 & 1.014 & 0.003 \\
\hline Log likelihood & \multicolumn{3}{|c|}{-6904} \\
\hline McFadden's $\mathrm{R}^{2}$ & \multicolumn{3}{|c|}{} \\
\hline
\end{tabular}

Significant at the 0.01 level $* * *, 0.05 * *, 0.1 *$

Source: own calculation based on Social Diagnosis

\section{Robustness}

To show the robustness of our results we explored the nature of age-related differences using logit models, in which except the binary variable for pension age, continuous measure of respondent age was applied. The estimates for age-related explanatory variables are presented in Table 7.

Table 7. Estimation results from logit models with alternative specification for ageing

\begin{tabular}{|l|l|c|c|}
\hline \multicolumn{1}{|c|}{ Working motivator } & \multicolumn{1}{|c|}{ Variable } & $\boldsymbol{\beta}$ & Odds ratio \\
\hline \multirow{2}{*}{ work matching one's skills } & age & $0.019^{* * *}$ & 1.019 \\
\cline { 2 - 4 } & pension age & 0.150 & 1.162 \\
\hline \multirow{2}{*}{ personal development opportunities } & age & $-0.033^{* * *}$ & 0.968 \\
\cline { 2 - 4 } & pension age & -0.139 & 0.870 \\
\hline \multirow{2}{*}{ stability of employment } & age & $0.007^{* *}$ & 1.007 \\
\cline { 2 - 4 } & pension age & $-0.423^{* * *}$ & 0.655 \\
\hline \multirow{2}{*}{ high degree of independence } & age & $0.008^{* * *}$ & 1.008 \\
\cline { 2 - 4 } & pension age & $0.461^{* *}$ & 1.586 \\
\hline \multirow{2}{*}{ appropriate pay } & age & -0.0005 & 0.999 \\
\cline { 2 - 4 } & pension age & $-0.276^{*}$ & 0.759 \\
\hline
\end{tabular}

Significant at the 0.01 level ${ }^{* *}, 0.05^{* *}, 0.1 *$.

Source: own calculation based on Social Diagnosis

The increase of workers' age results in systematic decrease of probability of choosing personal development as working motivator. In contrast, the older the worker, the higher the probability of him or her being motivated by work matching their skills. In both of the above cases, exceeding retirement age does not change the rate of increase or decrease of probability of choice of a particular working motivator. In con- 
trast, within the financial motivator achieving retirement age plays a crucial role. While the probability of choosing appropriate pay as working motivator is unaffected by systematic increase of workers age, those workers who achieve retirement age change their financial aspirations. It could be explained by obtaining pension rights.

We can explain the impact of age on the need for work stability in the same way. According to Table 7, the older the worker, the more probable it is that he or she will prefer stability of employment. After achieving the retirement age, the need for working in a stable environment stops to be so important, because the workers already have pension rights. Finally, it seems that the probability of being motivated by high degree of independence grows systematically when the age of the workers increases, but it starts to rise faster after they achieve retirement age.

\section{Conclusions}

The future of labour market is strongly connected with the demographic trends, which at present show ageing population and a decrease of workforce. One of the actions to be taken, which might guarantee the slowing down of the worker numbers' decline, is to convince elderly workers to continue their labour market activity. As for the need for people who achieved retirement age to continue working, one will need to adapt the working conditions to their needs.

In this paper we showed that the strategy of motivating people to work should account for age-related differences. What motivates elderly workers doesn't always motivate the others in the same way. Pre-retirement age workers prefer more than others to be independent and to have a job which is related to their experience. The financial motivators as well as the stability of employment, although very important for all workers, seem to be less important for the elderly ones, because they achieved pension rights.

\section{References}

Amershi B., Holmes S., Jablonski H., Keil M., Lüthi E., Matoba K. (2007), Poradnik szkoleniowy: zarządzanie różnorodnościa, Anti-Discrimination and Diversity Training VT/2006/009. Bleijenbergh I., Holgersson C., Ryan I . (2016), Diversity, diversity management and identity in organizations, "Equality, Diversity and Inclusion", no. 35(1), pp. 2-4.

Czapiński J., Panek T. (eds.) (2015), Diagnoza Społeczna 2015. Warunki i jakość życia Polaków. Raport, Rada Monitoringu Społecznego, Warszawa.

Duszczyk M., Lesińska M., Matuszczyk K. (2015), Upolitycznienie kwestii demograficznej (starzenia się ludności) w Polsce, "Studia i Materiały", no. 5, Ośrodek Badań nad Migracjami UW. Fazlagić J. (2014), Zarządzanie różnorodnością a zarządzanie wiedza , "E-mentor”, no. 1(53), pp. 54-61. Gruszczyński M. (ed.) (2012), Mikroekonometria: modele i metody analizy danych indywidualnych, Oficyna Wolters Kluwer business, Warszawa. 
GUS (2014), Prognoza ludności na lata 2014-2050. Studia i analizy statystyczne, Warszawa.

GUS (2016), Population. Size and structure and vital statistics in Poland by territorial division in 2015. As of December 31, Warszawa.

Harvey C.P., Allard M. (2015), Understanding and managing diversity, Pearson, Boston.

Kołodziejczyk-Olczak I . (2014), Zarządzanie pracownikami $w$ dojrzałym wieku, Wydawnictwo Uniwersytetu Łódzkiego, Łódź.

Kołodziejczyk-Olczak I . (2015), Wpływ zarzadzania wiekiem na zatrudnialność dojrzałych pracowników, "Edukacja Ekonomistów i Menedżerów: Problemy, Innowacje, Projekty”, no. 1(35), pp. $75-93$.

Lisowska E., Sznajder A. (2013), Zarządzanie różnorodnościa w miejscu pracy. Raport z I edycji Barometru Różnorodności, Konfederacja Lewiatan, Warszawa.

Maier M. (2015), Starzejace się społeczeństwo jako wyzwanie dla polityki społecznej i rodzinnej, "Prace Naukowe Uniwersytetu Ekonomicznego we Wrocławiu", no. 401.

Szczepański M. (2015), Ryzyko ubóstwa osób starszych a konstrukcja zreformowanego systemu emerytalnego w Polsce, "Zeszyty Naukowe Uniwersytetu Szczecińskiego. Finanse. Rynki Finansowe. Ubezpieczenia", no. 73, pp. 441-451.

Tompa E. (2002), The impact of health on productivity: empirical evidence and policy implications, "The Review of Economic Performance and Social Progress", no. 2.

United Nations Educational, Scientific, and Cultural Organization (2009), Investing in Cultural Diversity and Intercultural Dialogue, UNESCO Publishing.

Walczak W. (2011), Zarządzanie różnorodnościa jako podstawa budowania potencjału kapitału ludzkiego organizacji, "E-mentor", no. 3, pp. 11-19.

World Bank (2012), Poland: Aging and the Economy, http://www.worldbank.org [accessed: 3.08.2016].

World Health Organization (2011), Global Health and Ageing, NIH Publication no. 11-7737.

\section{Przyszłość polskiego rynku pracy a zagadnienie motywowania osób starszych do pracy}

Streszczenie: Zgodnie z prognozami demograficznymi populacja osób w wieku produkcyjnym - w ciągu kolejnych lat - zmaleje, podczas gdy udział osób w wieku 65 lat i więcej wzrośnie. Negatywne tendencje demograficzne odbiją się niekorzystnie na sytuacji na rynku pracy. Jeśli współczynnik aktywności zawodowej nie wzrośnie, łączna liczba osób pracujących drastycznie zmaleje. Presja demograficzna na rynku pracy powinna wpłynąć zatem na wydłużenie aktywności zawodowej Polaków. Wzrost aktywności zawodowej wydaje się jednym z kluczowych zagadnień dotyczących funkcjonowania rynku pracy w Polsce. Czynnikiem, który może przyczynić się do podniesienia wartości współczynnika aktywności zawodowej (w szczególności wśród osób w wieku przedemerytalnym), jest dostosowanie warunków pracy do potrzeb osób w różnym wieku. Możliwość pracy zdalnej, elastyczne godziny pracy czy też gratyfikacja finansowa mogą w innym stopniu motywować do pracy osoby młode i starsze. W rezultacie wykorzystywanie poszczególnych strategii motywacji do zwiększania aktywności zawodowej osób starszych wymaga zidentyfikowania rozwiązań, które w sposób najbardziej efektywny wspomagać będą pracę tej grupy pracowników. Celem pracy jest identyfikacja różnic w sposobie motywowania pracowników ze względu na ich wiek. W badaniu wykorzystano bazę danych indywidualnych, pochodzących z Diagnozy Społecznej (dane z 2015 r.). Do weryfikacji różnic motywacyjnych zastosowano modele logitowe. Uzyskane wyniki wskazują, że preferencje motywacyjne osób starszych różnią się od tych, jakie deklarują pozostali pracownicy. Osoby w wieku przedemerytalnym częściej niż inni deklarują potrzebę niezależności oraz preferują pracę zgodną z dotychczas nabytymi umiejętnościami. Gratyfikacja finansowa, jak również stabilizacja zatrudnienia, 
mimo iż są istotnymi motywatorami, odgrywają mniejszą rolę wśród osób starszych z uwagi na nabyte prawa emerytalne.

Słowa kluczowe: satysfakcja z pracy, rynek pracy, zarządzanie różnorodnością, zróżnicowanie ze względu na wiek

JEL: J14, J28, C25

\begin{tabular}{|l|l|}
\hline \multirow{2}{*}{ OPEN ACCESS } & $\begin{array}{l}\text { C by the author, licensee Łódź University - Łódź University Press, Łódź, Poland. } \\
\text { This article is an open access article distributed under the terms and conditions } \\
\text { of the Creative Commons Attribution license CC-BY } \\
\text { (http://creativecommons.org/licenses/by/3.0/) }\end{array}$ \\
\cline { 2 - 2 } & Received: 2016-08-14; verified: 2016-10-06. Accepted: 2017-05-22 \\
\hline
\end{tabular}

